\title{
REVIEW
}

Open Access

\section{The roles of ribosomal proteins in nasopharyngeal cancer: culprits, sentinels or both}

\author{
Edmund Ui-Hang $\operatorname{Sim}^{1 *}$ (D), Choon-Weng Lee ${ }^{2}$ and Kumaran Narayanan ${ }^{3,4}$
}

\begin{abstract}
Ribosomal protein genes encode products that are essential for cellular protein biosynthesis and are major components of ribosomes. Canonically, they are involved in the complex system of ribosome biogenesis pivotal to the catalysis of protein translation. Amid this tightly organised process, some ribosomal proteins have unique spatial and temporal physiological activity giving rise to their extra-ribosomal functions. Many of these extra-ribosomal roles pertain to cellular growth and differentiation, thus implicating the involvement of some ribosomal proteins in organogenesis. Consequently, dysregulated functions of these ribosomal proteins could be linked to oncogenesis or neoplastic transformation of human cells. Their suspected roles in carcinogenesis have been reported but not specifically explained for malignancy of the nasopharynx. This is despite the fact that literature since one and half decade ago have documented the association of ribosomal proteins to nasopharyngeal cancer. In this review, we explain the association and contribution of dysregulated expression among a subset of ribosomal proteins to nasopharyngeal oncogenesis. The relationship of these ribosomal proteins with the cancer are explained. We provide information to indicate that the dysfunctional extra-ribosomal activities of specific ribosomal proteins are tightly involved with the molecular pathogenesis of nasopharyngeal cancer albeit mechanisms yet to be precisely defined. The complete knowledge of this will impact future applications in the effective management of nasopharyngeal cancer.
\end{abstract}

Keywords: Ribosomal proteins, Nasopharyngeal carcinoma, Carcinogenesis, Cancer genetics, Medical genetics

\footnotetext{
* Correspondence: uhsim@unimas.my

${ }^{1}$ Faculty of Resource Science and Technology, Universiti Malaysia Sarawak, 94300 Kota Samarahan, Sarawak, Malaysia

Full list of author information is available at the end of the article
}

(c) The Author(s). 2021 Open Access This article is licensed under a Creative Commons Attribution 4.0 International License, which permits use, sharing, adaptation, distribution and reproduction in any medium or format, as long as you give appropriate credit to the original author(s) and the source, provide a link to the Creative Commons licence, and indicate if changes were made. The images or other third party material in this article are included in the article's Creative Commons licence, unless indicated otherwise in a credit line to the material. If material is not included in the article's Creative Commons licence and your intended use is not permitted by statutory regulation or exceeds the permitted use, you will need to obtain permission directly from the copyright holder. To view a copy of this licence, visit http://creativecommons.org/licenses/by/4.0/ The Creative Commons Public Domain Dedication waiver (http://creativecommons.org/publicdomain/zero/1.0/) applies to the data made available in this article, unless otherwise stated in a credit line to the data. 


\section{Background}

Eukaryotic ribosomal proteins (RPs) comprises 79 different known types that are broadly divided into two groups, the small (40S) and large (60S) ribosomal subunits. Since 2014, a revised naming system for RPs was published [1] and this is used in this review. In this improved alphanumeric nomenclature system, the prefixes $\mathrm{eS}$, and uS connote eukaryotic and universal ribosomal proteins of the small subunit respectively. The prefixes $\mathrm{eL}$, and $\mathrm{uL}$ connote eukaryotic and universal ribosomal proteins of the large subunit respectively.

Interestingly, albeit within an integrated system of transcriptional and translational regulation, some extent of uniqueness occurs among RPs in the defined physiological regulation of specific genes [2]. This gave rise to the cogent suspicion that RPs have physiological significance extraneous to ribosome biogenesis and protein biosynthesis. Indeed, as early as the mid-90s, evidence emerged to explain the extra-ribosomal functions of RPs that include DNA replication, transcription, DNA repair, DNA splicing and modification, and apoptosis [3]. Since then, there has been a steady increase in reports or findings documenting these extraneous functions of RPs [4-6] as listed in Table 1. The tight relationship of ribosomal proteins with cell development and differentiation through their extraribosomal functions also means that any altercation of their structures and/or expression can result in maldevelopment and malignancy. The physiological connection between RPs and cancers has also been extensively reviewed and explained [5, 6], including their interaction with the p53-MDM2 complex in events of carcinogenesis [7]. The focus of this review is confined to the relationships of RPs with nasopharyngeal carcinoma (NPC). This cancer begins as a malignant tumour at the epithelial lining of the nasopharynx, more precisely at the Fossa of Rosenmuller - a depression next to and above the opening of the Eustachian tube [8,9]. A comprehensive review on NPC-associated RPs (NRPs) and their significance in the NPC oncogenesis is timely to facilitate further endeavours on exploring NRPs as targets for diagnosis and prognostic biomarkers, and targeted drug therapy.

As such, this review covers what has been known thus far from the link between RPs and NPC, and what has been proposed regarding the molecular pathogenesis mediated by NPC-associated RPs (NRPs) in NPC situation. Literature reviewed here encompasses findings on cancer-associated RPs, current knowledge on NPC and NRPs, and information on the plausible biological roles of NRPs in the context of NPC carcinogenesis. Issues under discussion include the complex relationship between NRPs and NPC that highlights the complexities on the former's roles and mechanisms in the neoplasm
Table 1 Known possible extra-ribosomal functions of eukaryotic ribosomal proteins as derived from Warner and McIntosh, [4]; de las Heras-Rubio et al., [5]; Xu et al., [6]

\begin{tabular}{|c|c|}
\hline $\begin{array}{l}\text { Ribosomal } \\
\text { proteins }\end{array}$ & Extra-ribosomal functions \\
\hline $\begin{array}{l}\text { eL30, uS14, UL12, } \\
\text { uS13 }\end{array}$ & Inhibits its own pre-mRNA splicing \\
\hline $\mathrm{uL} 2, \mathrm{eS} 28$ & Shortens its own mRNA $T_{1 / 2}$ \\
\hline $\begin{array}{l}\text { uL18, uL5, uL14, } \\
\text { uL24, eS7 }\end{array}$ & Sequesters M/HDM2 from ubiquitinizing E3 \\
\hline uL5 & Sequesters c-Myc from transactivating its targets \\
\hline uL24 & Promotes p53 translation \\
\hline uL14 & $\begin{array}{l}\text { Negatively regulate Miz1 by sequestering } \\
\text { nucleophosmin }\end{array}$ \\
\hline RACK1 & $\begin{array}{l}\text { Cell signalling via acting as a receptor for protein } \\
\text { kinase } C\end{array}$ \\
\hline uL13 & $\begin{array}{l}\text { Inhibits mRNA translation (GAIT complex) subset of } \\
\text { inflammation-related proteins }\end{array}$ \\
\hline uS3 & $\begin{array}{l}\text { Act as a DNA endonuclease (apurinic/apyrimidinic } \\
\text { endonuclease III) for DNA repair; binds NFkB; and } \\
\text { serves as a signal mediator between neuronal } \\
\text { apoptosis and DNA repair }\end{array}$ \\
\hline uL16 & Binds c-jun \\
\hline uS10, eL6 & Influences Pol III transcription \\
\hline eL22 & $\begin{array}{l}\text { Binds Histone H1 (affects transcription), and forms a } \\
\text { RNP with Epstein-Barr-encoded small RNA (EBER-1) } \\
\text { in B lymphocytes }\end{array}$ \\
\hline eS26 & Susceptibility factor to diabetes \\
\hline uS10 & $\begin{array}{l}\text { Participates in anti-termination by RNA polymerase } \\
\text { III }\end{array}$ \\
\hline uL3 & $\begin{array}{l}\text { Induction of G1/S arrest or apoptosis by } \\
\text { modulating p21 }\end{array}$ \\
\hline uL10 & $\begin{array}{l}\text { DNA repair: apurinic/apyrimidinic endonuclease III; } \\
\text { promotes viral infection; and functions in viral } \\
\text { translation }\end{array}$ \\
\hline uS11 & Negatively controls splicing of its own pre-mRNA \\
\hline uS15 & Negatively controls splicing of its own pre-mRNA \\
\hline uL30 & $\begin{array}{l}\text { Inhibits the translation of specific mRNAs, including } \\
\text { its own }\end{array}$ \\
\hline eL19 & $\begin{array}{l}\text { Regulation of the Slit-Robo signalling pathway for } \\
\text { axon guidance and angiogenesis }\end{array}$ \\
\hline es1 & $\begin{array}{l}\text { Modulation of erythropoiesis, and binds to the } \\
\text { Epstein Barr virus encoded protein EBNA5 }\end{array}$ \\
\hline P2 & $\begin{array}{l}\text { Iron-binding protein responsible for distributing } \\
\text { iron intracellularly }\end{array}$ \\
\hline
\end{tabular}

of the latter; and the applicability of NRPs as biomarkers for NPC.

\section{Ribosomal proteins and cancers}

Early evidence of the association between RPs and cancers came from the observations of haploinsufficiency of eS4 in Turner Syndrome [10] and eS19 mutation in the Diamond-Blackfan Anaemia (DBA) condition [11]. Besides eS19, mutations and deregulation of several other 
RP genes have been reported to be associated with cancer in DBA individuals [12]. In colorectal cancer, numerous RP genes were reportedly dysregulated $[13,14]$ suggesting their roles in the regulation of cell proliferation, apoptosis, tumor suppressors, and malignant transformation/progression [15]. Besides colorectal malignancy, association of RPs to cancers includes uL14 in lung adenocarcinoma [16]; eL22 in T-cell acute lymphoblastic leukemia [17]; eL8, eL37, eS19, eS21, eS24, and eS27 in prostate cancer [18-20]; uS8 in breast cancer [21], eS27 in gastric carcinomas [22]; eL5 and eL14 in ovarian cancer [23]; and uS8 and RACK1 in liver cancer [24, 25]. Table 2 provides an overview of RP-associated cancer-related processes based on information from Xu et al. [6]

\section{Nasopharyngeal carcinoma (NPC)}

NPC patients present with a wide range of symptoms and are usually confirmed upon histopathological examination of tissue biopsies [26]. The World Health Organisation (WHO) classification of NPC constitutes three major types, that is the Type I, II, and III [27] with Type II being the most common [28]. NPC has moderate to high prevalence in Southern China, Southeast Asia, Arctic and North Africa [29-33] and particularly among the Cantonese in China [32, 33]. Early indication of genetic susceptibility to NPC came from the Human Leucocyte Antigen (HLA) factor [34]. This is followed by reports of allelic loss in chromosome 3p, 11q, and the inactivation of RASSF1A [35-37]. Besides this, a correlation between NPC pathogenesis and Epstein-Barr Virus (EBV) infection has been established [38] with higher EBV positivity in Type II compared to Type I NPC [39]. Environmental factors such as the over-consumption of salt-preserved food [40-42], cigarette smoking [40,41, 43], and cumulative exposure to formaldehyde [44] have been reportedly linked to the increased risk of NPC. Almost all NPC scenarios begin with EBV infection, but the concerted roles of genetic factors, viral infection, and environmental triggers are necessary for the manifestation of the disease.

Table 2 Plausible roles of RPs in tumorigenesis

\begin{tabular}{ll}
\hline Ribosomal proteins & $\begin{array}{l}\text { Cancer-related } \\
\text { processes }\end{array}$ \\
\hline uS3, eS1, eS6, eS7, uS11, eS25, eS27, uS14, uL3, eL6, & Apoptosis \\
uL30, uL2, uL14, uL24 & \\
uS3, uS7, eS6, eS7, uS11, uS19, eS19, eS10, eS25, eS26, & Cell cycle \\
eS27, eS31, uL3, uL18, eL6, uL30, uL5, eL13, uL14, uL24, & \\
eL31, eL34, eL37, eL41 & \\
eS6, uS4, uS15, uS11, uS8, eS24, eS27, eL6, uL2, uL5, & Cell \\
eL15, uL22, uL24, eL29, eL31, eL34, eL42 & proliferation \\
P1, eS1, uS11, uL18, eL22, eL41 & $\begin{array}{l}\text { Neoplastic } \\
\text { transformation }\end{array}$ \\
uS3, eS6, eS7, uS8, eS24, eS27, eL15 & $\begin{array}{l}\text { Cell migration } \\
\text { and invasion }\end{array}$ \\
\hline
\end{tabular}

\section{Diagnosis and treatment of NPC}

NPC is one of the most misdiagnosed cancers whereby a majority of reported cases are from advanced stages with poor prognosis. Only $9 \%$ of cases are detected at Stage I, while 83 and 39\% at Stages II/III, and IV respectively [45]. Conventional diagnosis is by nasopharyngeal endoscopy, lymph node histopathology, and immunoassay of EBV-derived antigens [46]. Biomarkers such as Galectin-1 [47], SRY-related HMG-box 4 (SOX4) [48], CXC chemokine receptor type 7 (CXCR7) [49], hypoxia up-regulated 1 (HYOU1) [50], Kelch Domain Containing 4 (KLHDC4) [51], Aldo-keto-reductase 1B10 (AKR1B10) [52], prohibitin-1 (PHB1) [53], and Cyclooxygnenase 2 (Cox-2) [54] have also been identified. A combined approach of using the $\mathrm{C}-\mathrm{C}$ motif chemokine ligand 27 (CCL27) biomarker and EBV-associated antigens can increase detection sensitivity [55]. Treatment of NPC depends on the location and invasiveness of the tumor, as well as the patient's overall health status. Early nonmetastatic stages (in situ tumors) is usually treated using the intensity-modulated radiotherapy (IMRT) [56]. Advanced stages are often managed using radiotherapy and chemotherapy (docetaxel, cisplatin or 5-fluorouracil) [57]. Recently, the molecule-based targeted therapy using Cetuximab (a chimeric monoclonal antibody that targets and inhibits the epidermal growth factor receptor, EGFR) concurrently with induction cisplatin-based chemoradiotherapy has significantly increased the overall survival rate of patients [58].

\section{Ribosomal proteins and nasopharyngeal carcinoma}

Initial findings of NPC-associated RP (NRP) were revealed in the elevated expression of metallopanstimulin 1 (MPS-1) in head and neck malignancies [59] - an RP encoded by the eS27 gene [60]. The transcript levels of eS27 and eS26 have also been found to be downregulated in NPC tissues [61]. Hence, besides establishing eS27 as the first NRP, an additional NRP (eS26) was identified. This baited the question on the full repertoire of NRPs. Indeed, a study by Fang and co-workers [62] revealed the transcripts of $u S 7$ and $u S 19$ to be upregulated in NPC tissues. It seems that the aberrant expressions of selected RP genes are connected with NPC tumorigenesis. The analysis of $18 \mathrm{RP}$ genes of the large ribosomal subunit component by comparing their expression pattern between NPC cell lines (derived from keratinising-differentiated and non-keratinising-poorly differentiated squamous cell carcinoma tumours of the nasopharynx) and normal control uncovered three RP genes (eL27, eL43, and eL41) to be significantly downregulated in the NPC cell lines [63]. However, a subsequent study revealed these three RP genes to be markedly over-expressed, in terms of transcript and protein levels, in NPC cell lines compared to normal control 
[64]. These conflicting results raised more confusion over the nature of the expression pattern of NRP genes between different studies. Nevertheless, in a later study involving more cell lines, four more RP genes ( $u S 8, u S 4$, $e S 31$, and $u L 14$ ) that are differentially expressed between cancer and normal cell lines were discovered [65]. These were down-regulated in NPC cell lines rather than upregulated. Finally, in a most recent study, the downregulation of $e L 14$ and up-regulation of $u S 19$ in NPC cell lines relative to normal control were reported [66]. This brings the repertoire of NRP genes to 12, comprising 5 and 7 members from the large and small ribosomal subunits respectively. Four and five RP genes are categorically up-regulated and down-regulated respectively, while four other RP genes are arguably inconsistent between studies. Table 3 summarises the latest list of NRP genes.

Despite the strong association of RPs with NPC carcinogenesis, little is known about their mechanism(s) in the malignancy. A problem here is their inconsistent expression patterns between different studies (Table 3). For example, early studies on eS27 [59] revealed its upregulation in NPC tissues relative to normal nasopharyngeal tissues. A subsequent study showed that it was down-regulated instead in NPC tissues [61]. Compounding this was a later study [67] that nullified both eS27 and $e S 26$ to be linked to NPC tumorigenesis. Similarly, the narrative of eL27, eL41, and eL43 changes when studied at different period despite using the same cancer models $[63,64]$. This phenomenon is difficult to elucidate and indicates the complex relationship between RP genes and NPC malignancy.

The disparity in expression patterns among the different NRP genes suggesting their unique behaviours in
NPC. Some NRPs are up-regulated while others are down-regulated (Table 3 ). There is no regular or predictable pattern. Is this irregularity due to their specialised activities during organogenesis? A possible answer to this is the fact that an intricate level of specialisation exists among RPs in the precise regulation of specific genes during cellular processes [2]. Since the activities of each NRP differ from one another, their dysregulation (albeit varied in nature) could concertedly contribute to carcinogenesis.

Another concern in the expression pattern of NRPs is that many of the findings are based on transcript (mRNA) levels. There is a possibility that posttranslational control involving the rapid degradation of surplus NRPs may balance the effects of differential transcript levels. However, a parallel pattern between differentially expressed mRNAs and proteins of three RP genes has been observed in the NPC cell lines [64]. In fact, in an in vivo study to compare mRNA and protein levels in an ovarian cancer model, differentially expressed mRNAs did correlate significantly with their protein products - better than in situation involving non-differentially expressed mRNAs [68]. Therefore, interpreting differentially expressed transcripts of selected RPs as NRPs is still relevant. Nevertheless, further studies to compare the mRNA and protein levels of all NRPs are needed to establish this relationship.

\section{Putative partners of ribosomal proteins in NPC scenario}

Before the discovery of NRPs, a preliminary indication of RP-linked NPC oncogenesis came from the observation of the association between eL22 and EBV. eL22 binds to one of the EBV-encoded RNAs, EBER-1 [69]

Table 3 List of differentially expressed RP genes in the context of NPC tumourigenesis

\begin{tabular}{|c|c|c|c|c|}
\hline Ribosomal subunit & RP genes & Expression level & NPC model & References \\
\hline \multirow[t]{4}{*}{ Large (60S) } & el14 & Up-regulated (transcript) & Cell lines & {$[66]$} \\
\hline & $u L 14$ & Down-regulated (transcript) & Cell lines & {$[65]$} \\
\hline & $\begin{array}{l}\text { el2 } 7^{a} \\
e L 47^{a} \\
e L 43^{a}\end{array}$ & Down-regulated (transcript) & Cell lines & {$[63]$} \\
\hline & $\begin{array}{l}e L 27^{a} \\
e L 41^{a} \\
e L 43^{a}\end{array}$ & Up-regulated (transcript and protein) & Cell lines & {$[64]$} \\
\hline \multirow[t]{8}{*}{ Small (40S) } & uS4 & Down-regulated (transcript) & Cell lines & {$[65]$} \\
\hline & uS7 & Up-regulated (transcript) & Tissues & {$[62]$} \\
\hline & uS8 & Down-regulated (transcript) & Cell lines & {$[65]$} \\
\hline & uS19 & Up-regulated (transcript) & Cell lines and tissues & {$[62,66]$} \\
\hline & es26 & Down-regulated (transcript) & Tissues & {$[61]$} \\
\hline & $e s 27^{a}$ & Up-regulated (protein) & Tissues & {$[59]$} \\
\hline & $e s 27^{a}$ & Down-regulated (transcript) & Tissues & {$[61]$} \\
\hline & es31 & Down-regulated (transcript) & Cell lines & {$[65]$} \\
\hline
\end{tabular}

${ }^{\mathrm{a}}$ Ribosomal protein genes that showed inconsistency in expression patterns between studies 
and EBERs have been known to enhance the proliferative capability of NPC cells [70]. Therefore, a role for EBV in NPC oncogenesis via the agency of NRPs is logical, specifically via the eL22-EBER-1 complex. In Burkitt's Lymphoma cell lines, elevated proliferation was attributed to the sequestration of eL22 by EBER-1 and its subsequent relocalisation from nucleoli to nucleoplasm [71]. Whether these events are similar in NPC scenario remain to be explored.

In the case of protein partners of NRPs, a prospective scenario is the RP-MDM2-p53 pathway. The tumour suppressor, p53 plays a pivotal function in cellular stability in response to nucleolar stress and is negatively regulated by a few factors, one of which is the Mouse Double Minute 2 homolog (MDM2) protein [72]. Incidentally, MDM2 interact directly with several types of RP such as uL4, uL5, uL14, uL18, uL24, eS7, and eS25 [73-75]. Except for uL24, these RPs bind to MDM2 to inhibit its function of ubiquitination and degradation of p53 during events of cellular stress. Conversely, uL24 is a direct translational activator of p53, and is itself negatively regulated by MDM2 [75]. p53 is the most frequently mutated gene in NPC [76] with specific mutation able to confer its oncogenic potential in NPC cells [77]. It is also linked to poor prognosis and worse survival rate of NPC patients, while MDM2 expression correlates with distant metastasis [78]. The connection between EBV infection and p53 expression in NPC oncogenesis [79, 80] may also include the hypothetical RP-MDM2-p53 pathway. In fact, there is now in silico evidence of plausible logical interactions between four EBV-related proteins with a myriad of RPs (Fig. 1) [81]. More specifically, the functional interactions between the Epstein-Barr nuclear antigen 1 (EBNA1) protein with four RPs individually via the complexes of EBNA1-eS10, EBNA1-eS25, EBNA1-uL10, and EBNA1-uL11 have been predicted. These are pertinent information not because EBNA1 is the only EBV protein found in all EBV-related malignancies $[82,83]$ but because it is the first time an EBVencoded protein is suspected to be associated with RPs. Although the biological relevance of these hypothetical interactions to NPC oncogenesis requires experimental proof, the most plausible candidate is the EBNA1-eS25 complex.

EBNA1 binds with the cellular ubiquitin-specific protease (USP7/HAUSP) [84, 85], in the same site as that recognised and bound by p53 and MDM2 [86]. In a way, EBNA1 competes with $\mathrm{p} 53 / \mathrm{MDM} 2$ in binding with USP7. The interaction between USP7 and p53/MDM2 affects the de-ubiquitination and stabilisation of p53 [87, 88]. When EBNA-1 binds to USP7 the latter is sequestered by the former thereby creating an environment where p53 cannot be stabilised (Fig. 2). eS25 has also been shown to bind to MDM2 and subsequently

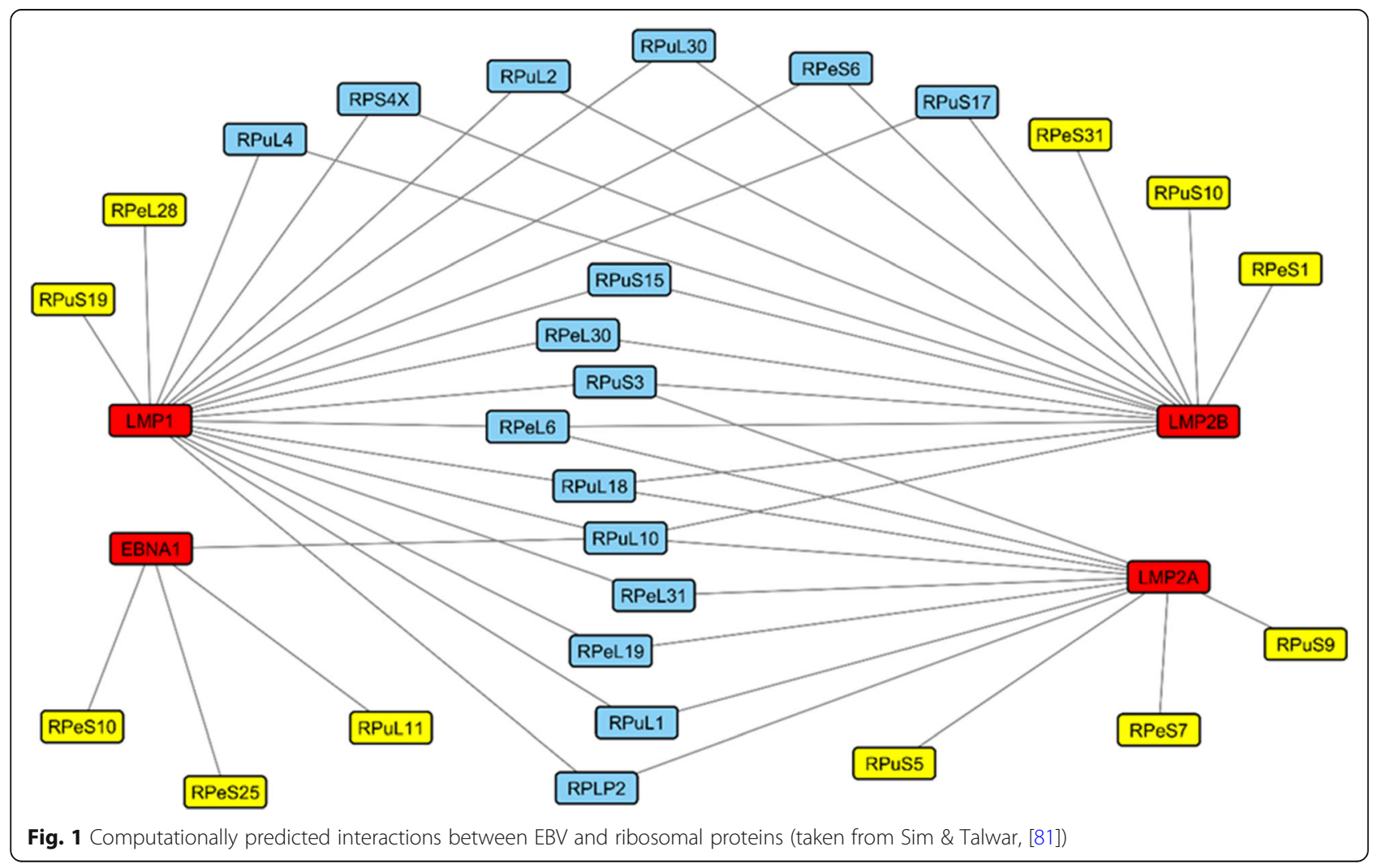




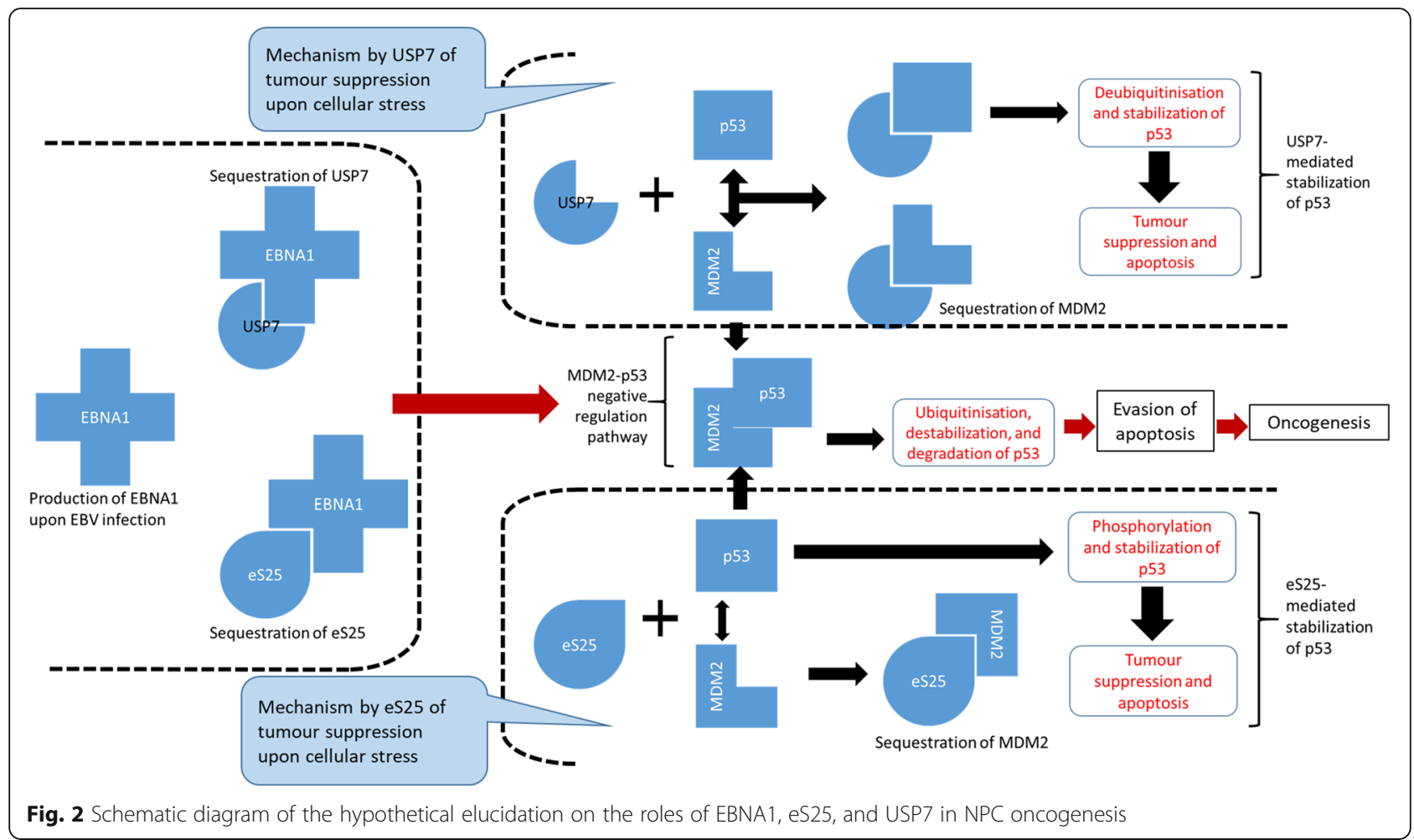

inhibiting MDM2 from destabilising p53 [74]. The sequestration of MDM2 by eS25 facilitates the activation and stabilisation of p53 (Fig. 2). eS25 and USP7 have the same effect on the MDM2-p53 pathway with the outcome of a stabilised p53. In the EBNA1USP7 scenario, a direct interaction between EBNA1 and USP7 has been experimentally proven [84]. The interaction between EBNA1 and eS25 is, however, only computationally predicted and requires experimental verification. Moreover, the direct association between EBNA1 and the MDM2-p53 complex is yet to be determined. It seems that the only way for EBNA1 to abrogate tumour suppression by $\mathrm{p} 53$ is via intermediary factors. Both USP7 and eS25 fit the description of such intermediary factors. A hypothetical elucidation of their roles in NPC oncogenesis is illustrated in Fig. 2.

Another relevant narrative based on our computational analysis is the predicted interaction between the EBV-encoded latent membrane protein 1, LMP1 and the RP, uS19 (Fig. 1). LMP1 is the principal viral oncoprotein of EBV [89] and is expressed in many human malignancies [90], including NPC [91]. The $u S 19$ transcript is overexpressed in NPC tissues [62] and cell lines [66]. The speculated interplay between LMP1 and uS19 during NPC oncogenesis can be anecdotally construed from literature other than their overexpression in NPC tissues/cells. LMP1 has been known to affect the normal functioning of p53 via various mechanisms. These include the inhibition of p53-mediated apoptosis through induction of the TNFAIP3/A20 pathway [92], phosphorylation-associated modification of p53 activity through the activation of the MAPK/SAPK pathway [93], overriding tumour suppressor activity of p53 by synergising with $\mathrm{Bcl}-2$ [94], and triggering expression of MDM2 to induce p53 degradation [95]. For uS19, its role in the activation of $\mathrm{p} 53$ via direct interaction with MDM2 has been reported [7]. By directly binding to MDM2, the E3 ubiquitin ligase activity of MDM2 is inhibited leading to p53 stabilisation. Combining literature knowledge of LMP1 and uS19 in this respect, we speculate that upon EBV infection of nasopharyngeal epithelial cells, LMP1 influences a series of molecular events that destabilises p53 including removing the regulatory role of uS19 in the MDM2-p53 pathway.

The latest discovery on the potential pathways mediated by NRP involves the eL27 protein. Initially, the mRNA transcript of this NRP was found to be downregulated in NPC cell lines [61] but later discovered its transcript and protein to be elevated [64]. Most recently and importantly, from a deeper analysis that included gene knockdown, protein profiling, and bioinformatics, 15 possible interacting partners of eL27 and their plausible roles in the pathogenesis of NPC (Fig. 3) were identified [96]. 


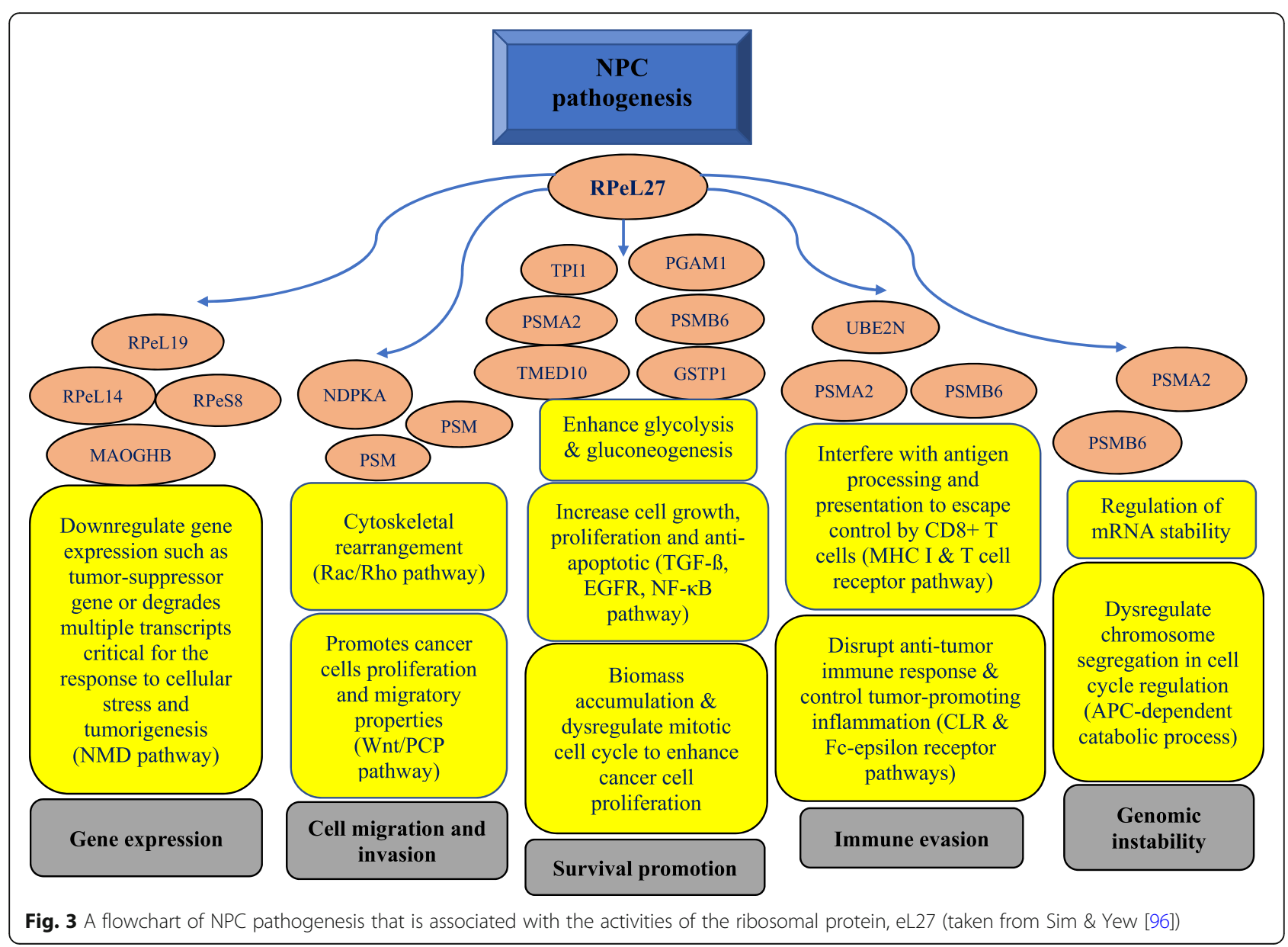

\section{Future outlook}

The connection between RPs and NPC is an established relationship not only because a sizable list of NRPs is available, but also that several putative RP-mediated pathways relevant to NPC malignancy are evident. This account is crucial in the prudent interpretation of the molecular basis of NPC. Biomedical applications will benefit immensely from this. Studies on chemical and molecular inducers/inhibitors of NRPs can be explored as one of the treatment regimes. Also, an NRP-based platform for molecular diagnosis and prognosis of NPC can be developed. Despite current advances in the understanding of NRPs, knowledge of the complex biochemical networks and molecular events mediated by them during NPC malignancy is still insufficient. It is because the expression behaviours of some NRPs are still elusive. In addition, more studies that look into their protein (rather than just transcript/mRNA) activity levels and functions will be required to firmly establish the nature of their relationship with NPC tumorigenesis. Whether NRPs can be labelled as culprits or sentinels or both in the context of NPC oncogenesis is unclear at the present moment. Deriving a definitive NRP-mediated pathway underlying the pathogenesis of NPC pathogenesis will ultimately require more extensive and in-depth studies.

\section{Conclusions}

Expression, functional, and bioinformatics studies over the years have cumulatively provided a considerable repertoire of NRPs and multiple proposed pathways. These provide essential insights into the molecular narrative of nasopharyngeal cancer that will aid future biomedical innovation in managing this disease. Nevertheless, in tandem with potential translational research, fundamental studies on the NRP-mediated molecular pathogenesis of NPC remain vital.

\section{Abbreviations}

AKR1B10: Aldo-keto-reductase 1B10; BCl-2: B-cell lymphoma 2; CCL27: C-C motif chemokine ligand 27; Cox-2: Cyclooxygnenase 2; CXCR7: CXC chemokine receptor type 7; DBA: Diamond-Blackfan Anaemia; DNA: Deoxyribonucleic acid; EBER: EBV-encoded small RNA; EBNA: Epstein-Barr nuclear antigen; EBV: Epstein-Barr Virus; EGFR: Epidermal growth factor receptor; HAUSP: Herpesvirus-associated ubiquitin-specific protease; HLA: Human Leucocyte Antigen; HMG: High mobility group; HYOU1: Hypoxia up-regulated 1; IMRT: Intensitymodulated radiotherapy; KLHDC4: Kelch Domain Containing 4; LMP: Latent membrane protein; MAPK/SAPK: Mitogen-activated protein kinases/stress-activated protein kinases; MDM2: Mouse Double Minute 2 
homolog; MPS-1: Metallopanstimulin 1; NPC: Nasopharyngeal carcinoma; NRP: NPC-associated RP; PHB1: Prohibitin-1; RACK1: Receptor for Activated C Kinase 1; RASSF1A: Ras Association Domain Family 1 Isoform A; RP: Ribosomal protein; SOX4: SRY-related HMG-box; SRY: Sexdetermining Region Y; TNFAIP3/A20: Tumor necrosis factor alpha-induced protein 3 or A20; USP7: Ubiquitin-specific peptidase or protease 7

\section{Acknowledgements}

Not applicable.

\section{Authors' contributions}

All authors were involved in the concept and design. EUHS wrote the manuscript. CWL and KN critically review the manuscript. All authors read and approved the final manuscript.

\section{Funding}

The authors received financial support from Malaysian Ministry of Science, Technology and Innovation (Grant Number: IRPA-PR 06-02-09-1020-PR0054/ 05-020), Ministry of Health (Grant Number: JPP-IMR 06-064), Ministry of Higher Education (Grant Numbers: RACE/a (1)/883/2012(01), FRGS/ST03(01)/ 962/2013(03), FRGS/ST03(02)/1299/2015(16), \& F07/TRGS/1520/2016), University of Malaya Research Collaboration Programme (Grant Number: UM.TNC2/ IPPP/PPGP/261/PRPUM), and the Universiti Malaysia Sarawak PhD Fund [Grant Number: F07(DPP08)/1160/2014(08)]. These funding bodies play no role in the design of the study and collection, analysis, and interpretation of data and in the writing of the manuscript. Open Access funding provided by Universiti Malaysia Sarawak.

\section{Availability of data and materials}

Not applicable.

\section{Declarations}

\section{Ethics approval and consent to participate}

Not applicable.

\section{Consent for publication}

Not applicable.

\section{Competing interests}

The authors declare that they have no competing interests.

\section{Author details}

${ }^{1}$ Faculty of Resource Science and Technology, Universiti Malaysia Sarawak, 94300 Kota Samarahan, Sarawak, Malaysia. ${ }^{2}$ Institute of Biological Sciences, University of Malaya, 50603 Kuala Lumpur, Malaysia. ${ }^{3}$ School of Science, Monash University, 46150 Bandar Sunway, Selangor, Malaysia. ${ }^{4}$ Department of Genetics and Genomics Sciences, Mount Sinai School of Medicine, New York, NY 10029, USA

\section{Received: 26 February 2021 Accepted: 20 June 2021}

\section{Published online: 30 June 2021}

\section{References}

1. Ban N, Beckmann R, Cate JH, Dinman JD, Dragon F, Ellis SR, et al. A new system for naming ribosomal proteins. Curr Opin Struct Biol. 2014;24:165-9. https://doi.org/10.1016/j.sbi.2014.01.002.

2. Komili S, Farny NG, Roth FP, Silver PA. Functional specificity among ribosomal proteins regulates gene expression. Cell. 2007;131(3):557-71. https://doi.org/10.1016/j.cell.2007.08.037.

3. Wool IG. Extraribosomal functions of ribosomal proteins. Trends Biochem Sci. 1996;21(5):164-5. https://doi.org/10.1016/S0968-0004(96)20011-8.

4. Warner JR, Mclntosh KB. How common are extraribosomal functions of ribosomal proteins? Mol Cell. 2009;34(1):3-11. https://doi.org/10.1016/j. molcel.2009.03.006.

5. de Las H-RA, Perucho L, Paciucci R, Vilardell J, LLeonart ME. Ribosomal proteins as novel players in tumorigenesis. Cancer Metastasis Rev. 2014; 33(1):115-41.

6. $X u X$, Xiong $X$, Sun $Y$. The role of ribosomal proteins in the regulation of cell proliferation, tumorigenesis, and genomic integrity. Sci China Life Sci. 2016; 59(7):656-72. https://doi.org/10.1007/s11427-016-0018-0.
7. Daftuar L, Zhu Y, Jacq X, Prives C. Ribosomal proteins RPL37, RPS15 and RPS20 regulate the Mdm2-p53-MdmX network. PLoS One. 2013;8(7):e68667. https://doi.org/10.1371/journal.pone.0068667.

8. Chua ML, Wee JT, Hui EP, Chan AT. Nasopharyngeal carcinoma. Lancet. 2016;387(10022):1012-24. https://doi.org/10.1016/S0140-6736(15)00055-0.

9. Chen YP, Chan ATC, Le QT, Blanchard P, Sun Y, Ma J. Nasopharyngeal carcinoma. Lancet. 2019;394(10192):64-80. https://doi.org/10.1016/S01406736(19)30956-0.

10. Fisher EM, Beer-Romero P, Brown LG, Ridley A, McNeil JA, Lawrence JB, et al. Homologous ribosomal protein genes on the human $X$ and $Y$ chromosomes: escape from $X$ inactivation and possible implications for turner syndrome. Cell. 1990;63(6):1205-18. https://doi.org/10.1016/0092-8674 (90)90416-C.

11. Draptchinskaia N, Gustavsson P, Andersson B, Pettersson M, Willig TN, Dianzani I, et al. The gene encoding ribosomal protein S19 is mutated in diamond-Blackfan anaemia. Nat Genet. 1999;21(2):169-75. https://doi.org/1 0.1038/5951.

12. Boria I, Garelli E, Gazda HT, Aspesi A, Quarello P, Pavesi E, et al. The ribosomal basis of diamond-Blackfan Anemia: mutation and database update. Hum Mutat. 2010;31(12):1269-79. https://doi.org/10.1002/ humu.21383.

13. Kasai H, Nadano D, Hidaka E, Higuchi K, Kawakubo M, Sato TA, et al. Differential expression of ribosomal proteins in human normal and neoplastic colorectum. J Histochem Cytochem. 2003;51(5):567-74. https:// doi.org/10.1177/002215540305100502.

14. Sim EUH, Bong IPN, Balraj P, Tan SK, Jamal R, Sagap I, et al. A preliminary study of differentially expressed genes in Malaysian colorectal carcinoma cases. J Biosci. 2006;17:19-37.

15. Lai MD, Xu J. Ribosomal proteins and colorectal cancer. Curr Genomics. 2007:8(1):43-9. https://doi.org/10.2174/138920207780076938.

16. Liu F, Li Y, Yu Y, Fu S, Li P. Cloning of novel tumor metastasis-related genes from the highly metastatic human lung adenocarcinoma cell line Anip973. J Genet Genomics. 2007;34(3):189-95. https://doi.org/10.1016/S1673-852 7(07)60020-4.

17. Rao S, Lee SY, Gutierrez A, Perrigoue J, Thapa RJ, Tu Z, et al. Inactivation of ribosomal protein $\mathrm{L} 22$ promotes transformation by induction of the stemness factor, Lin28B. Blood. 2012;120(18):3764-73. https://doi.org/10.11 82/blood-2012-03-415349.

18. Vaarala MH, Porvari KS, Kyllönen AP, Mustonen MV, Lukkarinen O, Vihko PT. Several genes encoding ribosomal proteins are over-expressed in prostatecancer cell lines: confirmation of L7a and L37 over-expression in prostatecancer tissue samples. Int J Cancer. 1998;78(1):27-32. https://doi.org/10.1 002/(SICI)1097-0215(19980925)78:1<27:*AID-IJC6>3.0.CO:2-Z

19. Arthurs C, Murtaza BN, Thomson C, Dickens $K$, Henrique R, Patel HRH, et al. Expression of ribosomal proteins in normal and cancerous human prostate tissue. PLoS One. 2017;12(10):e0186047. https://doi.org/10.1371/journal.pone. 0186047.

20. Fernandez-Pol JA, Fletcher JW, Hamilton PD, Klos DJ. Expression of metallopanstimulin and oncogenesis in human prostatic carcinoma. Anticancer Res. 1997;17(3A):1519-30.

21. Feng W, Liang C, Wang C, Yu X, Li Q, Yang H. Knockdown of ribosomal protein S15A inhibits proliferation of breast cancer cells through induction of apoptosis in vitro. Cytotechnology. 2018;70(5):1315-23. https://doi.org/1 0.1007/s10616-018-0221-9.

22. Wang YW, Qu Y, Li JF, Chen XH, Liu BY, Gu QL, et al. In vitro and in vivo evidence of metallopanstimulin-1 in gastric cancer progression and tumorigenicity. Clin Cancer Res. 2006;12(16):4965-73. https://doi.org/10.11 58/1078-0432 CCR-05-2316.

23. Kim J, Pak JH, Choi WH, Kim JY, Joo WD, Kim DY, et al. Detection of ovarian cancer-specific gene by differentially expressed gene polymerase chain reaction prescreening and direct DNA sequencing. Clin Oncol. 2007;25(18 suppl):21106. https://doi.org/10.1200/jco.2007.2 5.18_suppl.21106

24. Xu M, Wang Y, Chen L, Pan B, Chen F, Fang Y, et al. Down-regulation of ribosomal protein S15A mRNA with a short hairpin RNA inhibits human hepatic cancer cell growth in vitro. Gene. 2014;536(1):84-9. https://doi.org/1 0.1016/j.gene.2013.11.075.

25. Ruan $Y$, Sun $L$, Hao $Y$, Wang $L, X u$ J, Zhang $W$, et al. Ribosomal RACK1 promotes chemoresistance and growth in human hepatocellular carcinoma. J Clin Invest. 2012;122(7):2554-66. https://doi.org/10.1172/JCI58488. 
26. Stelow EB, Wenig BM. Update from the 4th edition of the World Health Organization classification of head and neck tumours: nasopharynx. Head Neck Pathol. 2017;11(1):16-22. https://doi.org/10.1007/s12105-0170787-0.

27. Putti TC, Tan KB. Pathology of nasopharyngeal carcinoma. In Lu JJ, Cooper JS, Lee AWM, editors. Nasopharyngeal cancer: Multidisciplinary management. Berlin: Springer; 2010. p. 71-80.

28. Hamdi Cherif M, Serraino D, Mahnane A, Laouamri S, Zaidi Z, Boukharouba $\mathrm{H}$, et al. Time trends of cancer incidence in Setif, Algeria, 1986-2010: an observational study. BMC Cancer. 2014;14(1):637. https://doi.org/10.1186/14 71-2407-14-637.

29. Torre LA, Bray F, Siegel RL, Ferlay J, Lortet-Tieulent J, Jemal A. Global cancer statistics, 2012. CA Cancer J Clin. 2015;65(2):87-108. https://doi.org/10.3322/ caac.21262.

30. Wided BA, Hamouda B, Hamadi H, Mansour BA. Nasopharyngeal carcinoma incidence in North Tunisia: negative trends in adults but not adolescents, 1994-2006. Asian Pac J Cancer Prev. 2015;16(7):2653-7. https://doi.org/10. 7314/APJCP.2015.16.7.2653.

31. Bray F, Ferlay J, Soerjomataram I, Siegel RL, Torre LA, Jemal A. Global cancer statistics 2018: GLOBOCAN estimates of incidence and mortality worldwide for 36 cancers in 185 countries. CA Cancer J Clin. 2018;68(6):394-424 Erratum in: CA Cancer J Clin. 2020;70(4):313.

32. Wu L, Li C, Pan L. Nasopharyngeal carcinoma: a review of current updates. Exp Ther Med. 2018;15(4):3687-92. https://doi.org/10.3892/etm.2018.5878.

33. Zhang SW, Chen WQ, Kong LZ, Li GL, Zhao P. An annual report: cancer incidence in 35 cancer registries in China, 2003. Bull Chin Cancer. 2007;16(7): 494-506.

34. Simons MJ, Wee GB, Day NE, Morris PJ, Shanmugaratnam K, De-Thé GB. Immunogenetic aspects of nasopharyngeal carcinoma: I. differences in HL-A antigen profiles between patients and control groups. Int I Cancer. 1974; 13(1):122-34. https://doi.org/10.1002/ijc.2910130114.

35. Hu LF, Eiriksdottir G, Lebedeva T, Kholodniouk I, Alimov A, Chen F, et al. Loss of heterozygosity on chromosome arm $3 p$ in nasopharyngeal carcinoma. Genes Chromosom Cancer. 1996;17(2):118-26. https://doi.org/1 0.1002/(SICI) 1098-2264(199610)17:2<118::AID-GCC7>3.0.CO;2-8.

36. Lung HL, Cheng Y, Kumaran MK, Liu ET, Murakami Y, Chan CY, et al. Fine mapping of the 11q22-23 tumor suppressive region and involvement of TSLC1 in nasopharyngeal carcinoma. Int J Cancer. 2004;112(4):628-35. https://doi.org/10.1002/ijc.20454.

37. Thieu HH, Lao TD, Le TA. Characterization of promoter hypermethylation of tumor suppressor gene RASSFIA and its association with the risk of nasopharyngeal carcinoma. Pharmacophore. 2020;11(3):56-62.

38. Tsao SW, Tsang CM, Lo KW. Epstein-Barr virus infection and nasopharyngeal carcinoma. Philos Trans R Soc Lond Ser B Biol Sci. 2017;372(1732):20160270. https://doi.org/10.1098/rstb.2016.0270.

39. Nakanishi $Y$, Wakisaka N, Kondo S, Endo K, Sugimoto H, Hatano M, et al. Progression of understanding for the role of Epstein-Barr virus and management of nasopharyngeal carcinoma. Cancer Metastasis Rev. 2017; 36(3):435-47. https://doi.org/10.1007/s10555-017-9693-X.

40. Yong SK, Ha TC, Yeo MC, Gaborieau V, McKay JD, Wee J. Associations of lifestyle and diet with the risk of nasopharyngeal carcinoma in Singapore: a case-control study. Chin J Cancer. 2017;36(1):3. https://doi.org/10.1186/s4 0880-016-0174-3.

41. Okekpa SI. S M N Mydin RB, Mangantig E, Azmi NSA, Zahari SNS, Kaur G, Musa Y. nasopharyngeal carcinoma (NPC) risk factors: a systematic review and meta-analysis of the association with lifestyle, diets, socioeconomic and sociodemographic in Asian region. Asian Pac J Cancer Prev. 2019;20(11): 3505-14. https://doi.org/10.31557/APJCP.2019.20.11.3505.

42. Huang T, Ploner A, Chang ET, Liu Q, Cai Y, Zhang Z, et al. Dietary patterns and risk of nasopharyngeal carcinoma: a population-based case-control study in southern China. Am J Clin Nutr. 2021. https://doi.org/10.1093/ajcn/ nqab114.

43. Chang ET, Liu Z, Hildesheim A, Liu Q, Cai Y, Zhang Z, et al. Active and passive smoking and risk of nasopharyngeal carcinoma: a population-based case-control study in southern China. Am J Epidemiol. 2017;185(12):127280. https://doi.org/10.1093/aje/kwx018.

44. Menicagli R, Bolla G, Menicagli L, Esseiridou A. Industrial pollutants and nasopharyngeal Cancer: an open question. Gulf J Oncolog. 2017:1 (24):70-4.

45. Grammatica L, Achille G, Piepoli S, Paradiso A. Early, late symptoms and histological type of nasopharyngeal carcinoma. Oncol Rep. 1999;6(6):1395-8. https://doi.org/10.3892/or.6.6.1395.
46. Chang ET, Adami HO. The enigmatic epidemiology of nasopharyngeal carcinoma. Cancer Epidemiol Biomark Prev. 2006;15(10):1765-77. https://doi. org/10.1158/1055-9965.EPI-06-0353.

47. Tang CE, Tan T, Li C, Chen ZC, Ruan L, Wang HH, et al. Identification of Galectin-1 as a novel biomarker in nasopharyngeal carcinoma by proteomic analysis. Oncol Rep. 2010;24(2):495-500.

48. Shi S, Cao X, Gu M, You B, Shan Y, You Y. Upregulated expression of SOX4 is associated with tumor growth and metastasis in nasopharyngeal carcinoma. Dis Markers. 2015;2015:658141.

49. Zhu L, Luo K, Gu XH, Hou N, Huang CP, Lou Q, et al. CXCR7 expression in nasopharyngeal carcinoma tissues correlates with disease severity. Int I Clin Exp Med. 2015;8(11):21257-61.

50. Zhou Y, Liao Q, Li X, Wang H, Wei F, Chen J, et al. HYOU1, regulated by LPLUNC1, is up-regulated in nasopharyngeal carcinoma and associated with poor prognosis. J Cancer. 2016;7(4):367-76. https://doi. org/10.7150/jca.13695

51. Lian YF, Yuan J, Cui Q, Feng QS, Xu M, Bei JX, et al. Upregulation of KLHDC4 predicts a poor prognosis in human nasopharyngeal carcinoma. PLoS One. 2016;11(3):e0152820. https://doi.org/10.1371/journal.pone.0152820.

52. He YC, Shen Y, Cao Y, Tang FQ, Tian DF, Huang CF, et al. Overexpression of AKR1B10 in nasopharyngeal carcinoma as a potential biomarker. Cancer Biomark. 2016;16(1):127-35. https://doi.org/10.3233/CBM-150548.

53. Liao Q, Guo X, Li X, Xiong W, Li X, Yang J, et al. Prohibitin is an important biomarker for nasopharyngeal carcinoma progression and prognosis. Eur J Cancer Prev. 2013;22(1):68-76. https://doi.org/10.1097/ CEJ.0b013e328354d351.

54. Sim CC, Sim EU. Over-expression of cyclo-oxygenase-2 predicts poor survival of patients with nasopharyngeal carcinoma: a meta-analysis. J Laryngol Otol. 2020;134(4):338-43. https://doi.org/10.1017/S002221512 0000614

55. Mao MJ, Xue N, Wang XP, Chi PD, Liu YJ, Huang Q, et al. Chemokine CCL27 is a novel plasma biomarker for identification the nasopharyngeal carcinoma patients from the Epstein-Barr virus capsid antigen-specific IgA seropositive population. BMC Cancer. 2018;18(1):9. https://doi.org/10.1186/ s12885-017-3718-2.

56. Kam MK, Leung SF, Zee B, Chau RM, Suen JJ, Mo F, et al. Prospective randomized study of intensity-modulated radiotherapy on salivary gland function in early-stage nasopharyngeal carcinoma patients. J Clin Oncol. 2007;25(31):4873-9. https://doi.org/10.1200/JCO.2007.11.5501.

57. Ekenel $\mathrm{M}$, Keskin $\mathrm{S}$, Basaran M, Ozdemir C, Meral R, Altun M, et al. Induction chemotherapy with docetaxel and cisplatin is highly effective for locally advanced nasopharyngeal carcinoma. Oral Oncol. 2011;47(7):660-4. https:// doi.org/10.1016/j.oraloncology.2011.04.010.

58. Peng $H$, Tang LL, Liu X, Chen L, Li WF, Mao YP, et al. Anti-epidermal growth factor receptor therapy concurrently with induction chemotherapy in locoregionally advanced nasopharyngeal carcinoma. Cancer Sci. 2018;109(5): 1609-16. https://doi.org/10.1111/cas.13589.

59. Stack BC Jr, Hollenbeak CS, Lee CM, Dunphy FR, Lowe VJ, Hamilton PD. Metallopanstimulin as a marker for head and neck cancer. World I Surg Oncol. 2004;2(1):45. https://doi.org/10.1186/1477-7819-2-45.

60. Tsui SK, Lee SM, Fung KP, Waye MM, Lee CY. Primary structures and sequence analysis of human ribosomal proteins L39 and S27. Biochem Mol Biol Int. 1996;40(3):611-6. https://doi.org/10.1080/15216549600201203.

61. Sim EUH, Toh AKL, Tiong TS. Preliminary findings of down-regulated genes in nasopharyngeal carcinoma. AsPac J Mol Biol Biotechnol. 2008;16(3):79-84.

62. Fang $W$, Li X, Jiang $Q$, Liu Z, Yang H, Wang S, et al. Transcriptional patterns, biomarkers and pathways characterizing nasopharyngeal carcinoma of southern China. J Transl Med. 2008;6(1):32. https://doi.org/10.1186/14795876-6-32.

63. Sim EU, Ang CH, Ng CC, Lee CW, Narayanan K. Differential expression of a subset of ribosomal protein genes in cell lines derived from human nasopharyngeal epithelium. J Hum Genet. 2010;55(2):118-20. https://doi. org/10.1038/jhg.2009.124.

64. Sim EU, Chan SL, Ng KL, Lee CW, Narayanan K. Human ribosomal proteins RPeL27, RPeL43, and RPeL41 are upregulated in nasopharyngeal carcinoma cell lines. Dis Markers. 2016;2016:5179594.

65. Sim EU, Ng KL, Lee CW, Narayanan K. The US8, uS4, eS31, and uL14 ribosomal protein genes are dysregulated in nasopharyngeal carcinoma cell lines. Biomed Res Int. 2017;2017:4876954.

66. Sim EUH, Chee CS, Vasudevan L, Ng KL, Chan SLL. Selective differential expression of the ribosomal protein genes eL14 and US19 in a well- 
differentiated epithelial cell line of nasopharyngeal carcinoma. Malays App Biol. 2018:47(1):247-53.

67. Ma XR, Sim EU, Ling TY, Tiong TS, Subramaniam SK, Khoo AS. Expression trend of selected ribosomal protein genes in nasopharyngeal carcinoma. Malays J Med Sci. 2012;19(4):23-30.

68. Koussounadis A, Langdon SP, Um IH, Harrison DJ, Smith VA. Relationship between differentially expressed mRNA and mRNA-protein correlations in a xenograft model system. Sci Rep. 2015;5(1):10775. https://doi.org/10.1038/ srep10775.

69. Fok V, Mitton-Fry RM, Grech A, Steitz JA. Multiple domains of EBER 1, an Epstein-Barr virus noncoding RNA, recruit human ribosomal protein L22. RNA. 2006;12(5):872-82. https://doi.org/10.1261/rna.2339606.

70. Iwakiri D, Sheen TS, Chen JY, Huang DP, Takada K. Epstein-Barr virusencoded small RNA induces insulin-like growth factor 1 and supports growth of nasopharyngeal carcinoma-derived cell lines. Oncogene. 2005; 24(10):1767-73. https://doi.org/10.1038/sj.onc.1208357.

71. Houmani JL, Davis Cl, Ruf IK. Growth-promoting properties of Epstein-Barr virus EBER-1 RNA correlate with ribosomal protein L22 binding. J Virol. 2009; 83(19):9844-53. https://doi.org/10.1128/JVI.01014-09.

72. Niazi S, Purohit M, Niazi JH. Role of p53 circuitry in tumorigenesis: a brief review. Eur J Med Chem. 2018;158:7-24. https://doi.org/10.1016/j.ejmech.201 8.08.099.

73. Zhang Y, Lu H. Signaling to p53: ribosomal proteins find their way. Cancer Cell. 2009;16(5):369-77. https://doi.org/10.1016/j.ccr.2009.09.024.

74. Zhang $X$, Wang $W$, Wang $H$, Wang $M H, X u$ W, Zhang R. Identification of ribosomal protein S25 (RPS25)-MDM2-p53 regulatory feedback loop. Oncogene. 2013;32(22):2782-91. https://doi.org/10.1038/onc.2012.289.

75. He X, Li Y, Dai MS, Sun XX. Ribosomal protein L4 is a novel regulator of the MDM2-p53 loop. Oncotarget. 2016;7(13):16217-26. https://doi.org/10.18632/ oncotarget.7479.

76. Dai W, Zheng H, Cheung AK, Lung ML. Genetic and epigenetic landscape of nasopharyngeal carcinoma. Chin Clin Oncol. 2016;5(2):16. https://doi.org/1 0.21037/cco.2016.03.06.

77. Qin ZQ, Li QG, Yi H, Lu SS, Huang W, Rong ZX, et al. Heterozygous p53R280T mutation enhances the oncogenicity of NPC cells through activating PI3K-Akt signaling pathway. Front Oncol. 2020;10:104. https://doi.org/10.33 89/fonc. 2020.00104.

78. Zhang P, Wu SK, Wang Y, Fan ZX, Li CR, Feng M, et al. p53, MDM2, eIF4E and EGFR expression in nasopharyngeal carcinoma and their correlation with clinicopathological characteristics and prognosis: a retrospective study. Oncol Lett. 2015;9(1):113-8. https://doi.org/10.3 892/ol.2014.2631.

79. Chatterjee K, Das P, Chattopadhyay NR, Mal S, Choudhuri T. The interplay between Epstein-Bar virus (EBV) with the p53 and its homologs during EBV associated malignancies. Heliyon. 2019;5(11):e02624. https://doi.org/10.1016/ j.heliyon.2019.e02624.

80. Lee IK, Linton RE, Nissom PM, Neilsen PM. Investigating the influence of Epstein-Barr virus on the p53 pathway in nasopharyngeal carcinoma. J Phys. 2019;1175(1):012078 IOP Publishing.

81. Sim EU, Talwar SP. In silico evidence of de novo interactions between ribosomal and Epstein - Barr virus proteins. BMC Mol Cell Biol. 2019;20(1):34. https://doi.org/10.1186/s12860-019-0219-y.

82. Ayee R, Ofori MEO, Wright E, Quaye O. Epstein Barr virus associated lymphomas and epithelia cancers in humans. J Cancer. 2020;11(7):1737-50. https://doi.org/10.7150/jca.37282.

83. Wilson JB, Manet E, Gruffat $H$, Busson P, Blondel M, Fahraeus R. EBNA1: oncogenic activity, immune evasion and biochemical functions provide targets for novel therapeutic strategies against Epstein-Barr virus associated cancers. Cancers. 2018;10(4):109. https://doi.org/10.3390/cancers1 0040109.

84. Holowaty MN, Zeghouf M, Wu H, Tellam J, Athanasopoulos V, Greenblatt J, et al. Protein profiling with Epstein-Barr nuclear antigen-1 reveals an interaction with the herpesvirus-associated ubiquitin-specific protease HAUSP/USP7. J Biol Chem. 2003;278(32):29987-94. https://doi.org/10.1074/ jbc.M303977200.

85. Jiang L, Xie C, Lung HL, Lo KW, Law GL, Mak NK, et al. EBNA1-targeted inhibitors: novel approaches for the treatment of Epstein-Barr virusassociated cancers. Theranostics. 2018;8(19):5307-19. https://doi.org/10.71 50/thno.26823.
86. Sheng Y, Saridakis V, Sarkari F, Duan S, Wu T, Arrowsmith CH, et al. Molecular recognition of p53 and MDM2 by USP7/HAUSP. Nat Struct Mol Biol. 2006;13(3):285-91. https://doi.org/10.1038/nsmb1067.

87. Li M, Chen D, Shiloh A, Luo J, Nikolaev AY, Qin J, et al. Deubiquitination of p53 by HAUSP is an important pathway for p53 stabilization. Nature. 2002; 416(6881):648-53. https://doi.org/10.1038/nature737.

88. Bhattacharya S, Chakraborty D, Basu M, Ghosh MK. Emerging insights into HAUSP (USP7) in physiology, cancer and other diseases. Signal Transduct Target Ther. 2018;3(1):17. https://doi.org/10.1038/s41392-018-0012-y.

89. Kanda T. EBV-encoded latent genes. Adv Exp Med Biol. 2018;1045:377-94. https://doi.org/10.1007/978-981-10-7230-7_17.

90. Ersing I, Bernhardt K, Gewurz BE. NF-KB and IRF7 pathway activation by Epstein-Barr virus latent membrane protein 1. Viruses. 2013;5(6):1587-606. https://doi.org/10.3390/v5061587.

91. Shair KHY, Reddy A, Cooper VS. New insights from elucidating the role of LMP1 in nasopharyngeal carcinoma. Cancers. 2018;10(4):86. https://doi.org/1 0.3390/cancers 10040086.

92. Fries KL, Miller WE, Raab-Traub N. Epstein-Barr virus latent membrane protein 1 blocks p53-mediated apoptosis through the induction of the A20 gene. J Virol. 1996;70(12):8653-9. https://doi.org/10.1128/jvi.70.12.86538659.1996.

93. Li L, Guo L, Tao Y, Zhou S, Wang Z, Luo W, et al. Latent membrane protein 1 of Epstein-Barr virus regulates $p 53$ phosphorylation through MAP kinases. Cancer Lett. 2007;255(2):219-31. https://doi.org/10.1016/j.canlet.2007.04.014.

94. Sheu LF, Chen A, Lee HS, Hsu HY, Yu DS. Cooperative interactions among p53, bcl-2 and Epstein-Barr virus latent membrane protein 1 in nasopharyngeal carcinoma cells. Pathol Int. 2004;54(7):475-85. https://doi. org/10.1111/j.1440-1827.2004.01654.x.

95. Wu HC, Lu TY, Lee JJ, Hwang JK, Lin YJ, Wang CK, et al. MDM2 expression in EBV-infected nasopharyngeal carcinoma cells. Lab Investig. 2004;84(12): 1547-56. https://doi.org/10.1038/labinvest.3700183.

96. Sim EUH, Yew KL. Putative target proteins of the ribosomal protein, RPeL27 in nasopharyngeal carcinoma cells. Malay J Biochem Mol Biol. 2019;22(3): 48-54.

\section{Publisher's Note}

Springer Nature remains neutral with regard to jurisdictional claims in published maps and institutional affiliations.
Ready to submit your research? Choose BMC and benefit from:

- fast, convenient online submission

- thorough peer review by experienced researchers in your field

- rapid publication on acceptance

- support for research data, including large and complex data types

- gold Open Access which fosters wider collaboration and increased citations

- maximum visibility for your research: over $100 \mathrm{M}$ website views per year

At BMC, research is always in progress.

Learn more biomedcentral.com/submissions 